\title{
Identification and Transport of Full-Length Amyloid Precursor Proteins in Rat Peripheral Nervous System
}

\author{
Sangram S. Sisodia, ${ }^{1,5}$ Edward H. Koo, ${ }^{6}$ Paul N. Hoffman, ${ }^{2,3}$ George Perry, ${ }^{7}$ and Donald L. Price ${ }^{1,3,4,5}$ \\ Departments of ${ }^{1}$ Pathology, ${ }^{2}$ Ophthalmology, ${ }^{3}$ Neurology, and ${ }^{4}$ Neuroscience and the 5 Neuropathology Laboratory, The \\ Johns Hopkins University School of Medicine, Baltimore, Maryland 21205-2196, ${ }^{6}$ Department of Neurology, Brigham and \\ Women's Hospital, Boston, Massachusetts, and 'Department of Pathology, Case Western Reserve University, Cleveland, \\ Ohio
}

\begin{abstract}
Amyloid deposits are a characteristic feature of the senile plaques identified in the brains of aged primates, individuals with Down's syndrome, and cases of Alzheimer's disease. The $\beta$-amyloid protein ( $A \beta$ ), the principal component of amyloid, is a $4 \mathrm{kDa}$ peptide derived from larger amyloid precursor protein(s) (APP). Four mRNAs, generated by alternative splicing of pre-mRNA derived from a single gene, encode $A \beta$-containing membrane glycoproteins termed APP$695,-714,-751$, and -770 ; the latter two isoforms contain a domain homologous to Kunitz protease inhibitors (KPI). The present study uses in vitro and in vivo strategies to examine the expression of APP in neurons of the dorsal root ganglia and the nature of APP transported in sciatic nerves of rats. Using quantitative in situ hybridization and semiquantitative PCR analysis, we document that mRNAs encoding APP-695 are expressed preferentially over transcripts that encode $\mathrm{KPI}$-containing isoforms in rat sensory ganglia. Furthermore, we provide compelling evidence that APP-695 is the predominant isoform synthesized in sensory neurons of the rat PNS and that full-length APP-695 and, to a lesser extent, APP-751/770 are rapidly transported anterogradely in axons.

IKey words: Alzheimer's disease, axonal transport, $\beta$-amyloid precursor protein, holo-APP-695, dorsal root ganglia (DRG), DRG expression]
\end{abstract}

The characteristic neuropathological feature of Alzheimer's disease (AD) is the presence of numerous senile plaques consisting of amyloid fibrils surrounded by cells and their processes (Wisniewski and Terry, 1973; Müller-Hill and Beyreuther, 1989; Selkoe, 1989). The principal component of these amyloid fibrils is $\beta$-amyloid protein (A $\beta$ ) (Glenner and Wong, 1984; Masters et al., 1985), an $\sim 4 \mathrm{kDa}$ peptide derived from larger amyloid precursor protein ( $\mathrm{PP}$ ) encoded by transcripts derived by alternative splicing of APP pre-mRNA (Goldgaber et al., 1987; Kang et al., 1987; Kitaguchi et al., 1988; Ponte et al., 1988;

\footnotetext{
Received Nuv. 27, 1992, revised Feb. 3, 1993; accepted Feb. 10, 1993.

We thank Dr. John W. Griffin for helpful discussions. These studies were supported by grants from the U.S. Public Health Service (NIH AG 05146, NS 20471, $A G 09287$, and AG 07552) as well as the American Health Assistance Foundation and the Metropolitan Life Foundation. D.L.P. is the recipient of a Leadership and Excellence in Alzheimer's Disease (LEAD) award (AG 07914) and a Javits Neuroscience Investigator Award (NS 10580). G.P. is the recipient of a Career Development Award (AG 00415).

Correspondence should be addressed to Sangram S. Sisodia, Ph.D., The Johns Hopkins University School of Medicine, Neuropathology Laboratory, 558 Ross Research Building, 720 Rutland Avenue, Baltimore, MD 21205-2196.

Copyright (C) 1993 Society for Neuroscience $0270-6474 / 93 / 133136-07 \$ 05.00 / 0$
}

Tanzi et al., 1988; Golde et al., 1990). APPs are integral membrane glycoproteins of $695,714,751$, and 770 amino acids with APP-751 and -770 containing regions structurally and functionally homologous to Kunitz protease inhibitors (KPI) (Oltersdorf et al., 1989; Van Nostrand et al., 1989).

Studies in cultured cells reveal that APP isoforms mature through the constitutive secretory pathway and are posttranslationally modified by the addition of $\mathrm{N}$ - and O-linked carbohydrates and by phosphorylation and tyrosine sulfation (Oltersdorf et al., 1989; Weidemann et al., 1989). Some full-length precursor appears on the plasma membrane (Weidemann et al., 1989; Haass et al., 1992a,b; Sisodia, 1992), and a fraction of cell surface-bound APP is cleaved (Haass et al., 1992a; Sisodia, 1992) within the $A \beta$ sequence (Esch et al., 1990; Sisodia et al., 1990; Anderson et al., 1991; Wang et al., 1991), an event that releases $\mathrm{C}$-terminally truncated APP derivatives into the conditioned medium. The presence of secreted APP derivatives in cerebrospinal fluid indicates that this pathway is utilized in vivo (Palmert et al., 1989; Weidemann et al., 1989). In addition, biochemical studies demonstrate that a fraction of membranebound APP is internalized and subsequently degraded in endosomal/lysosomal compartments (Cole et al., 1989; Estus et al., 1992; Golde et al., 1992; Haass et al., 1992a). Finally, in cultured cells, APPs arc associatcd with processing events that generate and release subfragments that contain the entire $\mathrm{A} \beta$ region (Haass et al., 1992a,b; Shoji et al., 1992).

APP isoforms are present in the PNS and CNS (Bahmanyar et al., 1987; Palmert et al., 1988; Johnson et al., 1990; Koo et al., 1990a,b), but neither the normal functions and processing of neural APP nor the cellular source(s) and mechanisms by which APP isoforms are processed to form $A \beta$ deposits in the brain parenchyma are well understood. It has been suggested that neuronal APPs are one source of $A \beta$ deposits in the brains of aged primates (Wisniewski and Terry, 1973; Struble et al., 1985; Selkoe et al., 1987; Walker et al., 1987; Cork et al., 1990; Martin et al., 1991), cases of Down's syndrome (Mann and Esiri, 1989; Rumble et al., 1989; Mann et al., 1992), and individuals with AD (Wisniewski and Terry, 1973; Cras et al., 1990; Probst et al., 1991; Kawai et al., 1992). Consistent with this idea are three findings: APPs are carried by rapid anterograde axonal transport (Koo et al., 1990a); APPs accumulate in neurites surrounding A $\beta$ plaques (Cork et al., 1990; Cras et al., 1991; Martin et al., 1991; Probst et al., 1991; Kawai et al., 1992; Mann et al., 1992); and there are anatomical relationships, particularly in terminal fields of the perforant pathway, between neurites and A $\beta$ deposits in cases of AD (Hyman et al., 1988, 1990; Cras et 
al., 1990; Probst et al., 1991; Kawai et al., 1992). To understand the mechanisms by which neuronal APPs participate in amyloidogenesis, it is essential to define the nature and characteristics of normally transported APP. As an initial step in these investigations, we document that APP-695 is the predominant isoform synthesized in lumbar sensory neurons and that APPs are transported anterogradely as a full-length species. Similar approaches can be used to examine the transport and processing in the normal CNS and in the CNS of animals that exhibit amyloid deposits (Struble et al., 1985; Selkoe et al., 1987; Cork el al., 1990; Martin et al., 1991).

\section{Materials and Methods}

Oligonucleotides. For PCR analysis, two 20-mer oligonucleotides were synthesized: a sense primer S640 (CGGACAGCATCGATTCTGCG), and an antisense primer AS1219 (CTCTCTCGGTGCTTGGCTTC). For in situ hybridization studies, two antisense oligonucleotides were used to detect APP-695 (J30) and APP-751/770 (I30), respectively. J30 (AGGAGGTAGTCCGAGTTCCCACGACGGCAG) is a 30-mer oligonucleotide encompassing 15 nucleotides on either side of the KPI insert (bases 851-880 of APP-695) (Shivers et al., 1988). I30 is a 30mer oligonucleotide complementary to bases 904-933 of APP-770.

Reverse transcriptase-polymerase chain reaction (RT-PCR) analysis. Sense and antisense oligonucleotides used in this analysis are described above. Total RNA was purified from L4 and L5 dorsal root ganglia (DRG) following homogenization of tissue in guanidinium thiocyanate and centrifugation of the lysate through a $\mathrm{CsCl}$ cushion (Chirgwin et al., 1979). For reverse transcription (RT), $2 \mu \mathrm{g}$ of total RNA and 50 pmol of antisense primer (AS1219) were heated to $65^{\circ} \mathrm{C}$, cooled, and then incubated with Moloney leukemia virus reverse transcriptase (Bethesda Research Laboratories, Gaithersburg, MD) and deoxynucleotide triphosphates at $42^{\circ} \mathrm{C}$. The reaction was terminated by heating to $95^{\circ} \mathrm{C}$ and diluting with $\mathrm{I} \times \mathrm{PCR}$ buffer $[50 \mathrm{~mm} \mathrm{KCl}, 10 \mathrm{~mm}$ Tris $\mathrm{HCl}(\mathrm{pH}$ $8.3), 1.5 \mathrm{mM} \mathrm{MgCl}_{2}, 0.01 \%$ gelatin]. The resulting mixture was divided into six aliquots; each aliquot was incubated in a PCR with $25 \mathrm{pmol}$ of sense primer ( $\mathrm{S} 640$ ), 4 pmol of ${ }^{32} \mathrm{P}-5^{\prime}$ end-labeled S640 primer, and 20 pmol of antisense primer (AS1219) in the presence of Taq DNA polymerase (Perkin Elmer-Cetus, Emeryville, CA). The sense primer was end labeled using T4 polynucleotide kinase and $\gamma{ }^{-32} \mathrm{P}$-adenosine triphosphate (ATP). Individual reactions were removed at either 18, 20, 21,22 , or 23 cycles, and one-quarter of each reaction was fractionated subsequently by electrophoresis on $2 \%$ agarose gels. Gels were first stained with ethidium bromide (EtBr) and photographed, and radioactive products were visualized following exposure of the dried gel to $\mathrm{x}$-ray film. Autoradiography (ARG) was performed at room temperature without intensifying screens. The intensity of resultant signals was quantified densitometrically, using a computerized image analysis system (Loats Associates, Inc., Westminster, MD), and the logarithm of the integrated optical densities was plotted as a function of cycle number. Equations of the linear regression lines were obtained using a leastsquares regression program (MacIntosh, CRICKET GRAPH).

In situ hybridization. Cryostat sections $(10 \mu \mathrm{m})$ were cut from lumbar DRG that had previously been frozen in a dry ice/ethanol bath. J30 and I30 synthetic oligonucleotides were $3^{\prime}$ end labeled with $\alpha{ }^{-35} \mathrm{~S}$-ATP using terminal deoxynucleotidyl transferase to specific activities of $\sim 2.5$ $\times 10^{7} \mathrm{cpm} / \mathrm{pm}$. Hybridization was performed in $50 \%$ formamide and $4 \times \operatorname{SSPE}\left(1 \times \mathrm{SSPE}=0.7 \mathrm{M} \mathrm{NaCl}, 40 \mathrm{~mm} \mathrm{NaH}_{2} \mathrm{PO}_{4}, 4 \mathrm{~mm}\right.$ EDTA, pH 7.4) at $37^{\circ} \mathrm{C}$ using $1 \mathrm{pm} / \mathrm{ml}$ of labeled-probe per section (Koo et al., 1990). Slides were rinsed at a final stringency of $1 \times \mathrm{SSC}$ at $40^{\circ} \mathrm{C}$, dipped in Kodak NTB-2 nuclear track emulsion, and then stained with cresyl violet. In situ images were analyzed using a computerized image analysis system (Loats Associates, Inc.) that quantifies silver grains as a function of cell cross-sectional area to generate grain density values.

Labeling/immunoprecipitation of explants and transfected cells. The L4 and L5 DRG, as well as a $2 \mathrm{~cm}$ segment of the sciatic nerve, were dissected from an adult rat $(\sim 250 \mathrm{gm})$ killed with $4 \%$ chloral hydrate. In parallel, we placed a ligature in the sciatic nerve of a second animal $\sim 3-4 \mathrm{~cm}$ distal to the L4/L5 DRG. After $10 \mathrm{~d}$, we dissected a $2 \mathrm{~cm}$ segment of the degenerating nerve distal to the ligature. Tissues were washed in Dulbecco's Modified Eagle Medium lacking methionine (DMEM-methionine), placed into $\sim 250 \mu \mathrm{l}$ of "labeling medium" consisting of DMEM-methionine, $1 \%$ dialyzed fetal calf serum, and $\sim 200$ $\mu \mathrm{Ci}$ of ${ }^{35} \mathrm{~S}$-methionine $(>1000 \mathrm{Ci} / \mathrm{mmol})$, and incubated at $37^{\circ} \mathrm{C}$ for 2 hr. Tissues were then washed with phosphate-buffered saline (PBS) and homogenized in immunoprecipitation buffer containing detergents and protease inhibitors [ $1 \times$ immunoprecipitation buffer $(150 \mathrm{~mm} \mathrm{NaCl}, 50$ mм Tris $\mathrm{HCl}$ ( $\mathrm{pH} 7.5), 5$ mм EDTA, $0.5 \% \mathrm{NP} 40,0.5 \% \mathrm{Na}$ deoxycholate) containing $50 \mu \mathrm{g} / \mathrm{ml}$ pepstatin $50 \mu \mathrm{g} / \mathrm{ml}$ leupeptin, $10 \mu \mathrm{g} / \mathrm{ml}$ aprotinin, $0.25 \mathrm{~mm}$ phenylmethylsulfonyl fluoride]. Sodium docedyl sulfate (SDS) was added to $0.25 \%$, and samples were subsequently boiled for $5 \mathrm{~min}$ and centrifuged at $15,000 \times \mathrm{g}$ for $5 \mathrm{~min}$. The pellet fraction was discarded, and APP-related molecules were immunoprecipitated from the soluble fraction with a polyclonal antibody CT15 raised against a synthetic peptide corresponding to the terminal 15 residues of APP, as previously described (Sisodia et al., 1990). Radioactive ( ${ }^{35} \mathrm{~S}-$ methionine) protein extracted into the soluble fraction was assayed by trichloroacetic acid (TCA) precipitation, as described (Gay et al., 1989). For immunoprecipitation of APP from DRG, nerve, and ligated-nerve extracts, we assayed $1.9 \times 10^{6}, 1.11 \times 10^{6}$, and $1.76 \times 10^{6} \mathrm{cpm}$ of TCA-insoluble protein, respectively.

For the labeling of transfected cells, Chinese hamster ovary $(\mathrm{CHO})$ cells stably transfected with complementary dioxyribonucleic acid(s) (cDNA) encoding human APP-695 or -770 were plated into miniwells and incubated at $37^{\circ} \mathrm{C}$ for $2.5 \mathrm{hr}$ in "labeling medium" containing 50 $\mu \mathrm{Ci}$ of ${ }^{35} \mathrm{~S}$-methionine. APP-related molecules were immunoprecipitated from detergent-solubilized cell extracts, as described above. Immunoprecipitates obtained from tissue or cell extracts were fractionated by SDS-PAGE (polyacrylamide gel electrophoresis) and visualized following fluorographic enhancement and exposure of the gel to $\mathrm{x}$-ray film (Sisodia et al., 1990)

Pulse labeling of lumbar DRG and immunoprecipitation. To pulse label proteins undergoing rapid axonal transport in lumbar sensory neurons, an adult rat was anesthetized with chloral hydrate, the left L4 and L5 DRG were exposed by laminectomy, and each DRG was injected with $2 \mu \mathrm{l}$ of ${ }^{35} \mathrm{~S}$-methionine $(250 \mu \mathrm{Ci} / \mu \mathrm{l})$ over a period of $10 \mathrm{~min}$ using a glass micropipette. Animals were killed with an overdose of anesthesia $4 \mathrm{hr}$ after injection. The DRG and a 4-cm-long segment of sciatic nerve were removed, and detergent-soluble extracts were prepared as described above. APP-related molecules from the detergent-soluble fraction of each homogenate were immunoprecipitated with polyclonal antibody CT15, described above, and RGP-3 raised against a synthetic peptide corresponding to APP residues 45-62.

\section{Results}

Lumbar sensory neurons express $m R N A$ encoding $A P P$ isoforms that lack KPI sequences

To assess the relative levels of transcripts encoding APP-695 and $-751 / 770$ in the DRG, we analyzed RNA prepared from L4 and L5 DRG by RT-PCR using an "antisense" primer complementary to APP sequences C-terminal to the KPI domain (Fig. 1A). Our preliminary studies established that the efficiency of cDNA synthesis directed by synthetic mRNA templates, which contained or lacked KPI-encoding sequences, was identical (S. S. Sisodia, unpublished observations), a result consistent with studies by Golde et al. (1990) that utilized a similar methodology to assess APP transcript levels in the brains of controls and individuals with $A D$. Products of the $R T$ reaction were incubated in a PCR with a ${ }^{32}$ P-labeled "sense" primer encoding sequences N-terminal to the KPI domain (Fig. $1 A$ ). Under these conditions, the PCR gives rise to three specific products of 350 , 518 , and 575 base pairs (bp) that represent mRNA encoding APP-695, -751, and -770, respectively. PCR products were fractionated by electrophoresis and stained with $\mathrm{EtBr}$ (Fig. 1B, left). Although an $\sim 350$ bp product is visualized by $\mathrm{EtBr}$ staining at cycles $22-24$, the 518 and 575 bp products are barely detectable. However, following exposure of the dried gel to $\mathrm{x}$-ray film, the $380 \mathrm{bp}$ as well as the 518 and 575 bp products are easily visualized (Fig. $1 B$, right). Because theoretical doubling of products of PCR drops as the cycle number is increased, we chose to examine the reaction over a defined rangc of cycles to obtain a linear amplification of products. In addition, we utilized com- 
A

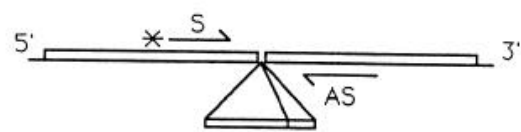

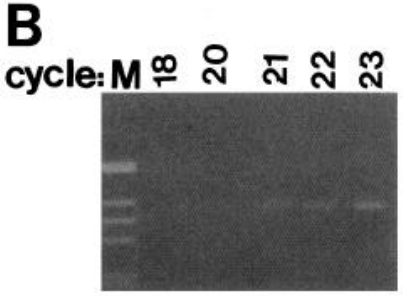

EtBr

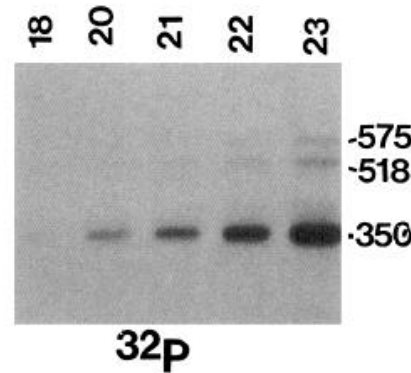

$-575$ .350

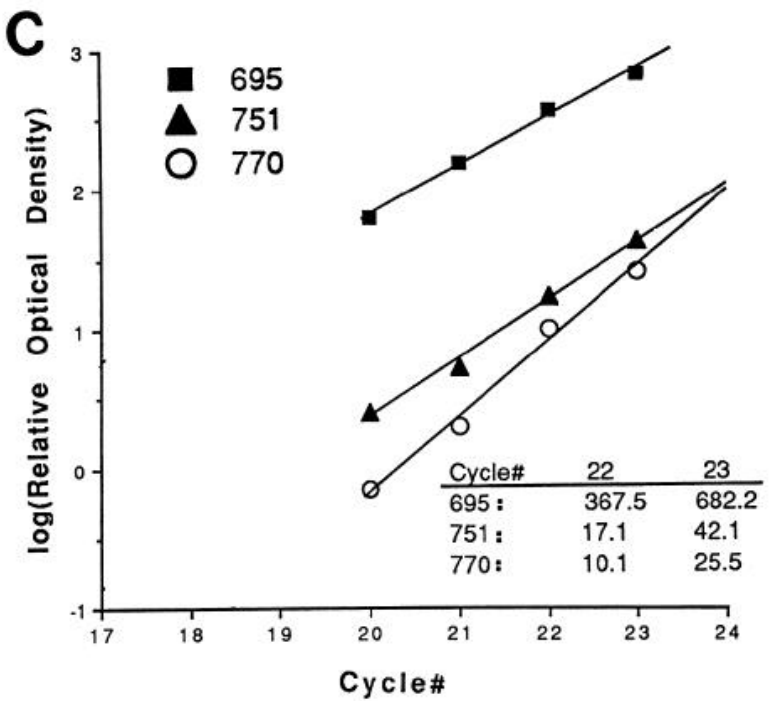

$$
\begin{array}{lll}
\text { 695: } y=.350 x-5.180 & R^{\wedge} 2=0.991 \\
751: y=.414 x-7.906 & R^{\wedge} 2=0.992 \\
77 n \cdot v=.538 x-10.927 & R^{\wedge} 2=0.990
\end{array}
$$

Figure 1. APP-695 mRNA is enriched in rat DRG. A, PCR strategy. For analysis of APP mRNA in DRG, RNA was reverse transcribed using antisense primer AS1219 $(A S)$. Reverse-transcribed products were subsequently incubated in a PCR with a ${ }^{32} \mathrm{P}-5^{\prime}$ end-labeled sense primer S640 $(S) . B$, PCR analysis of APP mRNA. Amplified products generated after $18,20,21,22$, or 23 cycles of the PCR procedure were fractionated by agarose electrophoresis and visualized by $\mathrm{EtBr}$ staining (left). The gel was subsequently exposed to $x$-ray film to visualize labeled products (right). PCR fragments (in bp) corresponding to amplified products were generated from transcripts encoding APP-695 (3509 bp), APP-751 (518 bp), and APP-770 (575 bp). C, Quantification of PCR procedure. Computer-assisted densitometry of an ARG of the dried gel was utilized to generate data points. Data are plotted as cycle number versus log of the relative optical density. Regression lines were computed using a leastsquares program. The equation for each regression line is presented below the graph and represented as a standard notation of $y=m y+b$, where $m$ is the slope and $b$ is the y-intercept. The slopes of each line are an indication of the relative efficiency of amplification of each set of products over the selected cycles. The inset depicts the raw values obtained by densitometry at 22 and 23 cycles.

puter-assisted densitometry to analyze the ARG images obtained following exposure of dried gels to film at room temperature without the sense of intensifying screens; data are summarized as a semilog plot (Fig. 1C). We have intentionally omitted the data for 18 cycles on this plot because signals for the APP-751 and -770 transcripts at 18 cycles were below the sensitivity of our image analysis system. Thus, our analysis only accounts for products obtained at cycles 20-23. The equation for each line presented at the bottom of Figure $1 C$ was derived by a least-squares regression method. Because the regression coefficient $\left(R^{2}\right)$ for each line is $\sim 1$, we are confident of the linearity of response for all three transcripts over the cycling range. Furthermore, the slopes of each line, particularly those that represent the APP-695 and -751 transcripts $(0.35$ and 0.41 , respectively), indicate that the relative efficiency of amplification is equivalent over the cycling range. Finally, the raw data obtained by densitometry at either 22 or 23 cycles, which are within the linear range of amplification (Fig. $1 C$, inset), document that mRNA encoding APP-695 is expressed at $\sim 10$-fold the total level of transcripts that encode KPI-containing APP in L4/L5 DRG.

\section{In situ hybridization}

In situ hybridization was used to define the cellular distribution of APP mRNA in DRG sensory neurons (Fig. 2). Using the J30 oligonucleotide, APP-695 transcripts were detected principally in sensory neurons of the DRG (Fig. $2 A$ ). The grain density was similar between large and small sensory neurons, with minor labeling in non-neuronal cells. In contrast, the I30 oligonucleotide, complementary to sequences encoding the KPI insert in APP-751/770, showed very low labeling in DRG neurons relative to the hybridization with the $\mathrm{J} 30$ probe (Fig. $2 B$ ). However, in the I30 oligonucleotide preparations, silver grains were apparent in association with non-neuronal cells, that is, fibroblasts or Schwann cells, that exhibited slightly higher average densities than those observed over sensory neurons. Because the two probes were of equal length, labeled to similar specific activities, and exposed to the emulsion for the same length of time, we are confident that the number of silver grains is indicative of the relative abundance of the respective APP mRNA species. For computer-assisted quantification of grain density, we selected a total of 111 neuronal profiles (representing 55 or 56 profiles for the KPI and APP-695 probes, respectively). Cells in each group were categorized on the basis of cross-sectional area (Fig. 2C). The results of our in situ hybridization study of neurons strongly suggest that these cells selectively express APP695 transcripts over KPI-encoded transcripts, irrespective of the size of the neuronal population being analyzed. The ratio of grain densities representing transcripts encoding APP-695 to KPI isoforms in small, intermediate, and large neurons was $\sim 9.7: 1, \sim 9.3: 1$, and $\sim 6: 1$, respectively. In parallel, we analyzed a population of non-neuronal cells in each section. Non-neuronal profiles were defined as those cells with cross-sectional areas of $<100 \mu \mathrm{m}^{2}$. As shown in Figure $2 C$, the grain density analysis of non-neuronal cells ("glia") showed that APP-695 transcripts exhibited an $\sim 2.7$-fold higher level of expression than KPI-encoded transcripts in these cells. Taken together with the results of PCR investigations, these studies provide strong evidence that mRNA encoding APP-695 is enriched relative to mRNA encoding KPI-containing isoforms in lumbar sensory neurons.

\section{APP-695 is more abundant than APP-751/770 in DRG}

To confirm that mRNA encoding various APP isoforms is translated efficiently in the PNS, we assessed, by in vitro labeling, the expression of APP-related polypeptides in both the DRG 
and the nerve. For this analysis, we compared the electrophoretic migration and glycosylation patterns of APP synthesized in the DRG or sciatic nerve to those synthesized in cultured cell lines transfected with either human APP-695 or -770 cDNA (Fig. 3). For in vitro labeling, L4 and L5 DRG (Fig. 3, lane 1), a $2 \mathrm{~cm}$ segment of sciatic nerve (lane 2), or a $2 \mathrm{~cm}$ segment of degenerated sciatic nerve (lane 3 ) was incubated in medium containing ${ }^{35} \mathrm{~S}$-methionine. In parallel, cultured $\mathrm{CHO}$ cells stably transfected with human cDNA encoding APP-695 (Fig. 3, lane 4) or APP-770 (lane 5) were labeled with ${ }^{35}$ S-methionine. After labeling, APPs were immunoprecipitated from detergentsoluble fractions with an antiserum generated against APP-695 residues 680-695 (CT15). Immunoprecipitates were fractionated by SDS-PAGE and visualized by ARG (Fig. 3). The specificity of this antisera for APP was verified by immunoprecipitation analysis of cultured cells transfected with APP cDNA (see below). We compared the glycosylation patterns of APP immunoprecipitated from DRG explants (Fig. 3) to previously documented patterns of APP synthesized in neuroblastoma cell lines or cells of neuroendocrine lineage (Weidemann et al., 1989); we assigned the $\sim 100 \mathrm{kDa}$ species to immature forms of APP695 synthesized in the endoplasmic reticulum and the $\sim 115-$ $125 \mathrm{kDa}$ species to APP-695 forms containing additional Golgiderived oligosaccharide modifications (Fig. 3, lane 1). Furthermore, the pattern of APP immunoprecipitated for DRG most closely resembled the immunoprecipitation pattern of APP synthesized in CHO cells that overexpress human APP-695 (lane 4). The principal APP isoforms synthesized by supporting cells of the sciatic nerve are likely to be APP-751/770, because the immunoprecipitation pattern (lane 2) most closely resembles that of CHO cells that overexpress human APP-770 (lane 5). Moreover, the induction of APP-751/770 synthesis is apparent in a degenerating nerve (lane 3 ) at a time when Schwann cell proliferation and macrophage reactions are maximal.

Although it appears that APP-695 is the predominant isoform synthesized in the DRG by virtue of comigration of these species with $\mathrm{CHO}$ cell-synthesized APP-695, we have detected some KPI-containing isoforms in DRG, as well, using an $\alpha$-KPI antibody (data not shown).

\section{Full-length APP-695 is transported in rat peripheral nerve}

To analyze the in vivo transport of APP in sensory fibers of sciatic nerve, ${ }^{35} \mathrm{~S}$-methionine was microinjected into the lumbar DRG, and labeled APPs were immunoprecipitated from sciatic nerve (Fig. 4). For immunoprecipitation, we utilized an APPspecific C-terminal antiserum, described above, and an N-terminal serum, RGP-3, generated against APP residues 45-62 (Perry et al., 1988; Cras et al., 1990). For this analysis, we

Figure 2. In situ hybridization with APP-695- and APP-751/770specific probes in rat DRG. $A$ and $B$, Bright-field photomicrographic images of rat DRG following in situ hybridization with ${ }^{35} \mathrm{~S}$-labeled oligonucleotide probes $\mathrm{J} 30(A)$ and $\mathrm{I} 30(B)$ complementary to mRNA encoding APP-695 and APP-751/770, respectively. Slides were counterstained with cresyl violet to demarcate cell boundaries. Magnification, $1120 \times . C$, Computer-assisted densitometry was utilized to determine average grain densities in neuronal and non-neuronal profiles following hybridization of the $\mathrm{J} 30$ and $\mathrm{I} 30$ probes. We selected 18 non-neuronal profiles for both the KPI and APP-695 probes. In our analysis, the average area (and range) for non-neuronal cells was $46.02 \mu \mathrm{m}^{2}(26.95-$ $\left.67.39 \mu \mathrm{m}^{2}\right)$ and $51.02 \mu \mathrm{m}^{2}\left(26.95-76.93 \mu \mathrm{m}^{2}\right)$ for the KPI and APP695 hybridizations, respectively. The numbers above each bar represent the number of profiles selected for analysis. Error bars represent SEM.
A $\quad 695$
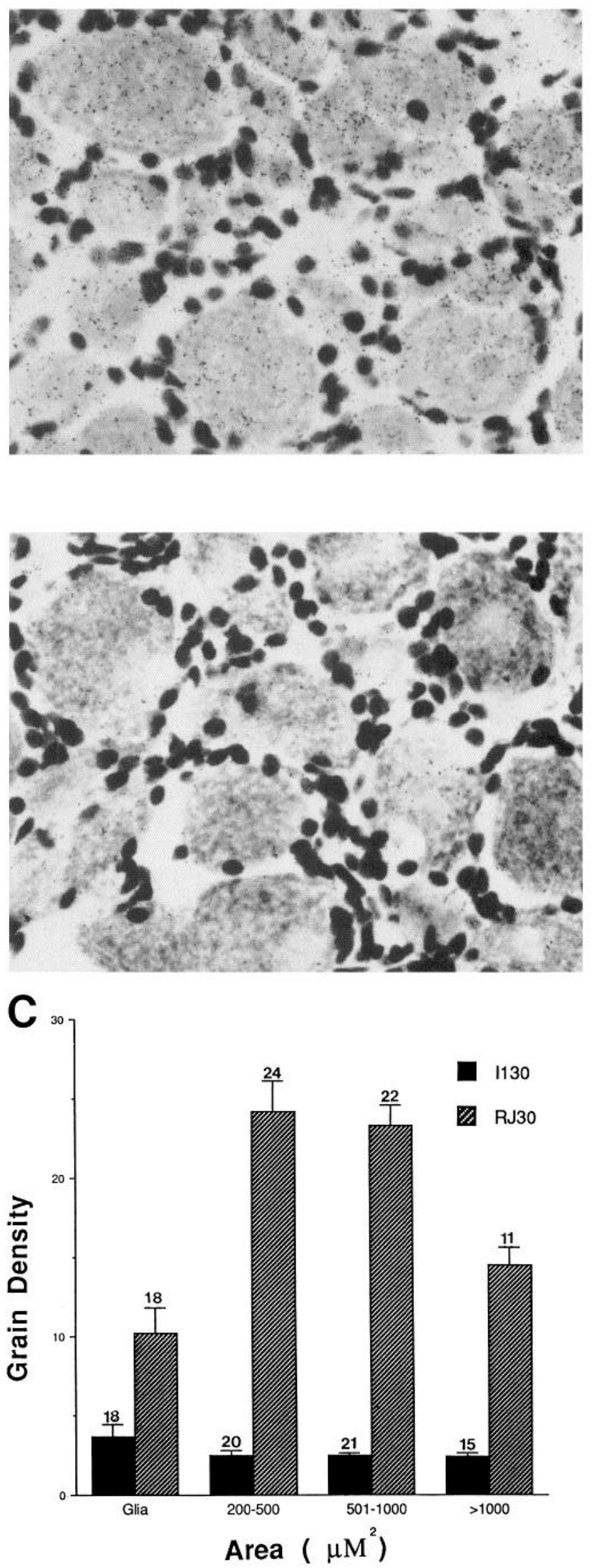


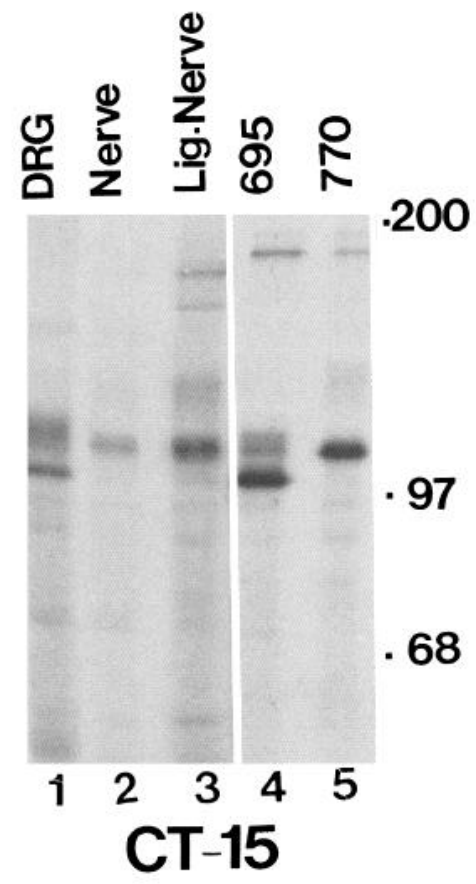

Figure 3. Analysis of APP expressed in DRG and sciatic nerve explants: comparison to human APP-695 and -770, C-terminal antibody immunoprecipitation. Lanes $I$ and 2 represent holo-APP forms synthesized in DRG or normal sciatic nerve, respectively. Lane 3 represents APP synthesized in a nerve that has degenerated for $10 \mathrm{~d}$ following ligation. Lanes 4 and 5 represent holo-APP forms synthesized in $\mathrm{CHO}$ cells stably transfected with human APP-695 and -770 cDNA, respectively. Molecular weights of size markers are in $\mathrm{kDa}$.

assumed that the rate of fast axonal transport is between 8 and $16 \mathrm{~mm} / \mathrm{hr}$ (i.e., $\sim 200-400 \mathrm{~mm} / \mathrm{d}$ ). Accordingly, animals were killed $4 \mathrm{hr}$ following injection of ${ }^{35} \mathrm{~S}$-methionine into the DRG. The DRG (Fig. 4, lanes 1,3) and a segment of sciatic nerve extending 2-4 cm from the ganglia (lanes 2,4 ) were isolated, and APP was immunoprecipitated from detergent-soluble extracts prepared from each tissue. An essentially indistinguishable pattern of intracellular APP forms was immunoprecipitated from ganglia with either $\mathrm{N}$ - or $\mathrm{C}$-terminal antisera (Fig. 4, compare lanes 1,3 ). The pattern of APP-related products is identical to that observed from ganglia labeled in vitro (compare Fig. 3, lane 1, with Fig. 4, lane 3), whereas the pattern of immunoprecipitated APP in the nerve discloses that the most abundant APP-related species likely represent the fully glycosylated $(\sim 120$ $125 \mathrm{kDa}$ ) forms of APP-695 (Fig. 4, lanes 2, 4). Presumably, this species matures through the Golgi apparatus and is then transported anterograde in axons. Although the mature APP695 forms of $\sim 120-125 \mathrm{kDa}$ are the predominant species in axons, we also detected small amounts ( $\sim 5 \%$ of all transported full-length molecules) of $\sim 140-150 \mathrm{kDa}$ in nerve on longer ARG exposures (Fig. 4, lane $4^{\prime}$ ). It is likely that the $\sim 140-150$ $\mathrm{kDa}$ products represent the most highly glycosylated forms of APP-751/770. We arrived at this conclusion based on the observation that sciatic nerves labeled in vitro also gave rise to immunoprecipitable APP forms of $\sim 125$ and $\sim 140-150 \mathrm{kDa}$ (Fig. 3, lanes 2,3). In any event, the relative abundance of fulllength APP-695 and APP-751/770-related species immunoprecipitated with C-terminal antibodies from nerve closely parallels the transcript levels detected in sensory neurons by in situ hybridization (Fig. 2). Thus, the demonstration that fully glyco-

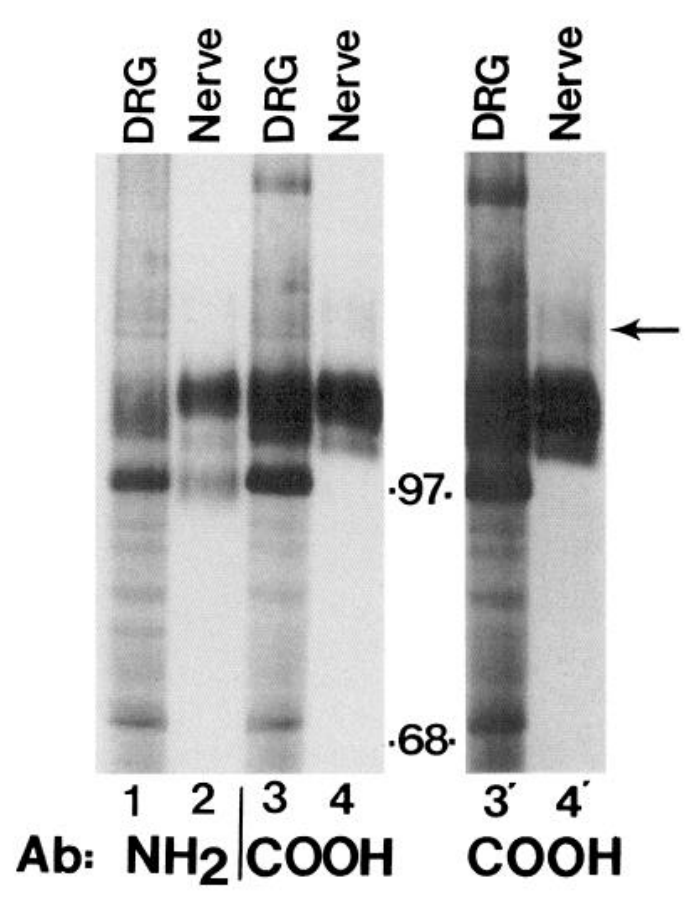

Figure 4. Transport of full-length APP in sciatic nerve. Rat L4/L5 DRG were injected with ${ }^{35} \mathrm{~S}$-methionine, and transport was allowed to occur for $4 \mathrm{hr}$. Subsequently, the ganglia and nerve segments were dissected, homogenized, and subjected to immunoprecipitation analysis with APP-specific N- or C-terminal antibodies. Lanes $I$ and 2 represent APP-related molecules derived from DRG or nerve, respectively, immunoprecipitated with APP N-terminal antibody RGP-3 $\left(\mathrm{NH}_{2}\right)$. Lanes 3 and 4 represent APP-related molecules derived from DRG or nerve, respectively, immunoprecipitated with APP C-terminal antibody CT 15 $(\mathrm{COOH})$. Lanes $3^{\prime}$ and 4 'represent a long exposure of lanes 3 and 4 and document the presence of $\sim 150 \mathrm{kDa}$, APP-related species (arrow) in the nerve, which likely represent transported post-Golgi forms of APP-751/770. Molecular weights of size markers are in kDa.

sylated APPs synthesized in sensory neurons are present in axons and retain C-terminal epitopes (Fig. 4, lanes $4,4^{\prime}$ ) provides unambiguous proof that APPs are transported as full-length species. Moreover, the vast majority of transported APP is fulllength protein, because comparable levels of fully glycosylated APP are recovered from the nerve using either $\mathrm{N}$ - or $\mathrm{C}$-terminal antibodies that also immunoprecipitate similar levels of APP from ganglia (Fig. 4, compare lanes 1, 3 with lanes 2, 4).

Although the principal isoform being transported appears to be APP-695, it is apparent that labeled APP-751/770 isoforms are also detected in the axon. The fact that levels of transported isoforms parallel levels of transcripts in sensory neurons provides strong evidence against selective trafficking of post-Golgi forms of APP-695 and APP-751/770 into the axonal compartment. It should also be noted that the $\mathrm{N}$-terminal antibody also detected a minor $(<10 \%)$ APP-related species of $\sim 95-100 \mathrm{kDa}$ in the nerve (Fig. 4, lane 2) that is not recognized by the C-terminal antibody (compare to Fig. 4, lane 4). This $\sim 95-100 \mathrm{kDa}$ APP-related species may represent a truncated product generated following axolemmal insertion of holo-APP. Some rapidly transported molecules are, in part, inserted into the axolemma (Griffin et al., 1981), and preliminary evidence suggests that, in the rabbit optic nerve, a fraction of APP synthesized by retinal ganglion neurons may be inserted into the axolemma (Morin et al., 1991). By analogy, we suggest that some truncated APP may be generated following insertion into the axolemma. 


\section{Discussion}

In earlier studies, we utilized a double-ligation paradigm to document that APPs synthesized in rat DRG are anterogradely transported in peripheral nerves (Koo et al., 1990a). Following the placement of ligatures on the sciatic nerve, we compared the rates of accumulation of APP and AChE, a rapidly transported protein. The rates of accumulation of immunologically detectable APP and AChE activity at the ligature were indistinguishable, an observation consistent with the idea that APPs are carried by fast anterograde axonal transport. These initial studies could not define the transported isoforms or determine the size/structurc becausc of local proteolysis of APP by intrinsic and extrinsic cellular responses to nerve damage at the ligature.

The present report clarifies these issues. First, PCR analysis of APP mRNA in DRG revealed that the level of mRNA encoding APP-695 was 10-fold higher than transcripts encoding the KPI forms (Fig. 1). Second, quantitative in situ hybridization demonstrated that mRNA encoding APP-695 is expressed between $\sim 6.1$ - and $\sim 9.7$-fold the level of KPI-encoded mRNA in sensory neurons (Fig. 2). This result was corroborated by the observation that the electrophoretic migration of the predominant APP species synthesized in pulsed-labeled DRG (Fig. 4) or DRG labeled as explants (Fig. 3) resembled human APP-695 synthesized in transfected CHO cells. Moreover, holo-APP-695 appears to be the principal transported isoform, but the presence of transported holo-APP-751/770 was clearly documented in an experiment where lumbar sensory ganglia were labeled with radioactive amino acid precursors, and APPs contained within the pulsed-labeled "wave" of rapidly transported molecules were immunoprecipitated (Fig. 4). In either case, the preponderant fraction of radiolabeled APP recovered from normal peripheral nerves is completely mature, post-Golgi isoforms that retain the extreme C-terminus; that is, they are full length.

These studies provide compelling evidence that APP-695 is the principal isoform transported in the rat peripheral nerve. It is likely that the transmembrane glycoprotein is transported as part of membranous vesicles that are translocated, via kinesinmediated motors, along microtubules. Furthermore, our preliminary studies in several pathways of the CNS also demonstrate that APP-695 is transported in a full-length form (data not shown), and it is likely that holo-APPs are transported anterogradely to distal axons and nerve terminals. Ongoing efforts are designed to define the trafficking and processing of transported APP at tcrminals in the CNS. Available evidence indicates that APPs are processed both at the plasma membrane (Sisodia, 1992) and in lysosomal/endosomal compartments (Golde et al., 1992; Haass et al., 1992a). We speculate that alterations of the normal processing of neuronal APP at synaptic sites may generate amyloidogenic fragments that, upon additional proteolysis, form $\mathrm{A} \beta$ deposits in the brain parenchyma of aged individuals (Struble et al.., 1985; Selkoe et al., 1987; Abraham et al., 1989; Cork et al., 1990), subjects with Down's syndrome (Mann and Esiri, 1989; Rumble et al., 1989; Mann et al., 1992), and patients with AD (Wisniewski and Terry, 1973; Probst et al., 1991).

\section{References}

Abraham CR, Selkoe DJ, Potter H, Price DL, Cork LC (1989) $\alpha_{1}$ Antichymotrypsin is present together with the $\beta$-protein in monkey brain amyloid deposits. Neuroscience 32:715-720.

Anderson JP, Esch FS, Keim PS, Sambamurti K, Lieberburg I, Robakis
NK (1991) Exact cleavage site of Alzheimer amyloid precursor in neuronal PC-12 cells. Neurosci Lett 128:126-128.

Bahmanyar S, Higgins GA, Goldgaber D, Lewis DA, Morrison JH, Wilson MC, Shankar SK, Gajdusek DC (1987) Localization of amyloid $\beta$ protein messenger RNA in brains from patients with Alzheimer's disease. Science 237:77-79.

Chirgwin JM, Przybyla AE, MacDonald RJ, Rutter WJ (1979) Isolation of biologically active ribonucleic acid from sources enriched in ribonuclease. Biochemistry 18:5294-5299.

Cole GM, Huynh TV, Saitoh T (1989) Evidence for lysosomal processing of amyloid $\beta$-protein precursor in cultured cells. Neurochem Res 14:933-939.

Cork LC, Masters C, Beyreuther K, Price DL (1990) Development of senile plaques. Relationships of neuronal abnormalities and amyloid deposits. Am J Pathol 137:1383-1392.

Cras P, Kawai M, Siedlak S, Mulvihill P, Gambetti P, Lowery D, Gonzalez-DeWhitt P, Greenberg B, Perry G (1990) Neuronal and microglial involvement in $\beta$-amyloid protein deposition in Alzheimer's disease. Am J Pathol 137:241-246.

Cras P, Kawai M, Lowery D, Gonzalez-DeWhitt P, Greenberg B, Perry $G$ (1991) Senile plaque neurites in Alzheimer disease accumulate amyloid precursor protein. Proc Natl Acad Sci USA 88:7552-7556.

Esch FS, Keim PS, Beattie EC, Blacher RW, Culwell AR, Oltersdorf T, McClure D, Ward PJ (1990) Cleavage of amyloid $\beta$ peptide during constitutive processing of its precursor. Science 248:1122-1124.

Estus S, Golde TE, Kunishita T, Blades D, Lowery D, Eisen M, Usiak M, Qu X, Tabira T, Greenberg BD, Younkin SG (1992) Potentially amyloidogenic, carboxyl-terminal derivatives of the amyloid protein precursor. Science 255:726-728.

Gay DA, Sisodia SS, Cleveland DW (1989) Autoregulatory control of $\beta$-tubulin mRNA stability is linked to translation elongation. Proc Natl Acad Sci USA 86:5763-5767.

Glenner GG, Wong CW (1984) Alzheimer's disease: initial report of the purification and characterization of a novel cerebrovascular amyloid protein. Biochem Biophys Res Commun 120:885-890.

Golde TE, Estus S, Usiak M, Younkin LH, Younkin SG (1990) Expression of $\beta$ amyloid protein precursor mRNAs: recognition of a novel alternatively spliced form and quantitation in Alzheimer's disease using PCR. Neuron 4:253-267.

Golde TE, Estus S, Younkin LH, Selkoe DJ, Younkin SG (1992) Processing of the amyloid protein precursor to potentially amyloidogenic derivatives. Science 255:728-730.

Goldgaber D, Lerman MI, McBride OW, Saffiotti U, Gajdusek DC (1987) Characterization and chromosomal localization of a cDNA encoding brain amyloid of Alzheimer's disease. Science 235:877-880.

Griffin JW, Price DL, Drachman DB, Morris J (1981) Incorporation of axonally transported glycoproteins into axolemma during nerve regeneration. J Cell Biol 88:205-214.

Haass C, Koo LEH, Mellon A, Hung AY, Selkoe DJ (1992a) Targeting of cell-surface $\beta$-amyloid precursor protein to lysosomes: alternative processing into amyloid-bearing fragments. Nature 357:500-503.

Haass C, Schlossmacher MG, Hung AY, Vigo-Pelfrey C, Mellon A, Ostaszewski BL, Lieberburg I, Koo EH, Schenk D, Teplow DB, Selkoe DJ (1992) Amyloid $\beta$-peptide is produced by cultured cells during normal metabolism. Nature 359:322-325.

Hyman BT, Van Hoesen GW, Wolozin BL, Davies P, Kromer LJ, Damasio AR (1988) Alz-50 antibody recognizes Alzheimer-related neuronal changes. Ann Neurol 23:371-379.

Hyman BT, Van Hoesen GW, Damasio AR (1990) Memory-related neural systems in Alzheimer's disease: an anatomic study. Neurology 40:1721-1730.

Johnson SA, McNeill T, Cordell B, Finch CE (1990) Relation of neuronal APP-751/APP-695 mRNA ratio and neuritic plaque density in Alzheimer's disease. Science 248:854-857.

Kang J, Lemaire H-G, Unterbeck A, Salbaum JM, Masters CL, Grzeschik K-H, Multhaup G, Beyreuther K, Müller-Hill B (1987) The precursor of Alzheimer's disease amyloid A4 protein resembles a cellsurface receptor. Nature 325:733-736.

Kawai M, Cras P, Richey P, Tabaton M, Lowery DE, Gonzalez-DeWhitt PA, Greenberg BD, Gambetti P, Perry G (1992) Subcellular localization of amyloid precursor protein in senile plaques of Alzheimer's disease. Am J Pathol 140:947-958.

Kitaguchi N, Takahashi Y, Tokushima Y, Shiojiri S, Ito H (1988) Novel precursor of Alzheimer's disease amyloid protein shows protease inhibitory activity. Nature 331:530-532. 
Koo EH, Sisodia SS, Archer DR, Martin LJ, Weidemann A, Beyreuther K, Fischer P, Masters CL, Price DL (1990a) Precursor of amyloid protein in Alzheimer disease undergoes fast anterograde axonal transport. Proc Natl Acad Sci USA 87:1561-1565.

Koo EH, Sisodia SS, Cork LC, Unterbeck A, Bayney RM, Price DL (1990b) IDifferential expression of amyloid precursor protein mRNAs in cases of Alzheimer's disease and in aged nonhuman primates. Neuron 2:97-104.

Mann DMA, Esiri MM (1989) The pattern of acquisition of plaques and tangles in the brains of patients under 50 years of age with Down's syndrome. J Neurol Sci 89:169-179.

Mann DMA, Jones D, South PW, Snowden JS, Neary D (1992) Deposition of amyloid $\beta$ protein in non-Alzheimer dementias: evidence for a neuronal origin of parenchymal deposits of $\beta$ protein in neurodegenerative disease. Acta Neuropathol (Berl) 83:415-419.

Martin LJ, Sisodia SS, Koo EH, Cork LC, Dellovade TL, Weidemann A, Beyreuther K, Masters C, Price DL (1991) Amyloid precursor protein in aged nonhuman primates. Proc Natl Acad Sci USA 88: $1461-1465$.

Masters CL, Multhaup G, Simms G, Pottgiesser J, Martins RN, Beyreuther K (1985) Neuronal origin of a cerebral amyloid: neurofibrillary tangles of Alzheimer's disease contain the same protein as the amyloid of plaque cores and blood vessels. EMBO J 4:2757-2763.

Morin PJ, Abraham CR, Johnson RJ, Fine RE (1991) Axonal transport and subcellular distribution of amyloid precursor protein (APP) of Alzheimer's disease. J Cell Biol 115:474a.

Müller-Hill B, Beyreuther K (1989) Molecular biology of Alzheimer's disease. Annu Rev Biochem 58:287-307.

Oltersdorf T, Fritz LC, Schenk DB, Lieberburg I, Johnson-Wood KL, Beattie EC, Ward PJ, Blacher RW, Dovey HF, Sinha S (1989) The secreted form of the Alzheimer's amyloid precursor protein with the Kunitz domain is protease nexin-II. Nature 341:144-147.

Palmert MR, Golde TE, Cohen ML, Kovacs DM, Tanzi RE, Gusella JF, Usiak MF, Younkin LH, Younkin SG (1988) Amyloid protein precursor messenger RNAs: differential expression in Alzheimer's disease. Science 241:1080-1084.

Palmert MR, Podlisny MB, Witker DS, Oltersdorf T, Younkin LH, Selkoe DJ, Younkin SG (1989) The $\beta$-amyloid protein precursor of Alzheimer disease has soluble derivatives found in human brain and cerebrospinal fluid. Proc Natl Acad Sci USA 86:6338-6342.

Perry G, Lipphardt S, Kancherla M, Gambetti P, Maggiora L, Lobl T, Mulvihill P, Mijares M, Sharma S, Cornette J, Greenberg B (1988) Amyloid precursor protein in senile plaques of Alzheimer's disease. Lancet 2:746.

Ponte P, Gonzalez-DeWhitt P, Schilling J, Miller J, Hsu D, Greenberg B, Davis K, Wallace W, Lieberburg I, Fuller F, Cordell B (1988) A new $A 4$ amyloid mRNA contains a domain homologous to serine proteinase inhibitors. Nature 331:525-532.

Probst A, Iangui D, Ipsen S, Robakis N, Ulrich J (1991) Deposition of $\beta / \mathrm{A} 4$ protein along neuronal plasma membranes in diffuse senile plaques. Acta Neuropathol (Berl) 83:21-29.

Rumble B, Retallack R, Hilbich C, Simms G, Multhaup G, Martins R, Hockey A, Montgomery P, Beyreuther K, Masters CL (1989) Amyloid A4 protein and its precursor in Down's syndrome and Alzheimer's disease. N Engl J Med 320:1446-1452.

Selkoe DJ (1989) Biochemistry of altered brain proteins in Alzheimer's disease. Annu Rev Neurosci 12:463-490.

Selkoe DJ, Bell DS, Podlisny MB, Price DL, Cork LC (1987) Conservation of brain amyloid proteins in aged mammals and humans with Alzheimer's disease. Science 235:873-877.

Shivers BD, Hilbich C, Multhaup G, Salbaum M, Beyreuther K, Seeburg PH (1988) Alzheimer's disease amyloidogenic glycoprotein: expression pattern in rat brain suggests a role in cell contact. EMBO J 7:1365-1370.

Shoji M, Golde TE, Ghiso J, Cheung TT, Estus S, Shaffer LM, Cai X-D, McKay DM, Tintner R, Frangione B, Younkin S (1992) Production of the Alzheimer amyloid $\beta$ protein by normal proteolytic processing. Science 258:126-129.

Sisodia SS (1992) $\beta$-Amyloid precursor protein cleavage by a membrane-bound protease. Proc Natl Acad Sci USA 89:6075-6079.

Sisodia SS, Koo EH, Beyreuther K, Unterbeck A, Price DL (1990) Evidence that $\beta$-amyloid protein in Alzheimer's disease is not derived by normal processing. Science 248:492-495.

Struble RG, Price DL Jr, Cork LC, Price DL (1985) Senile plaques in cortex of aged normal monkeys. Brain Res 361:267-275.

Tanzi RE, McClatchey AI, Gusella JF (1988) Molecular genetics of the Alzheimer's amyloid peptide precursor gene. In: Current communications in molecular biology, the molecular biology of Alzheimer's disease (Finch CE, Davies P, eds), pp 95-100. Cold Spring Harbor, NY: Cold Spring Harbor Laboratory.

Van Nostrand WE, Wagner SL, Suzuki M, Choi BH, Farrow JS, Geddes JW, Cotman CW, Cunningham DD (1989) Protease nexin-II, a potent antichymotrypsin, shows identity to amyloid $\beta$-protein precursor. Nature 341:546-549.

Walker LC, Kitt CA, Schwam E, Buckwald B, Garcia F, Sepinwall J, Price DL (1987) Senile plaques in aged squirrel monkeys. Neurobiol Aging 8:291-296.

Wang R, Meschia JF, Cotter RJ, Sisodia SS (1991) Secretion of the $\beta / A 4$ amyloid precursor protein. Identification of a cleavage site in cultured mammalian cells. J Biol Chem 266:16960-16964.

Weidemann A, König G, Bunke D, Fischer P, Salbaum JM, Masters $\mathrm{CL}$, Beyreuther K (1989) Identification, biogenesis, and localization of precursors of Alzheimer's disease A4 amyloid protein. Cell 57: $115-126$.

Wisniewski HM, Terry RD (1973) Reexamination of the pathogenesis of the senile plaque. In: Progress in neuropathology, Vol II (Zimmerman HM, ed), pp 1-26. New York: Grune \& Stratton. 